\title{
Role of deep sponge grounds in the Mediterranean Sea: a case study in southern Italy
}

\author{
Marzia Bo • Marco Bertolino • Giorgio Bavestrello • \\ Simonepietro Canese $\cdot$ Michela Giusti $\cdot$ Michela Angiolillo • \\ Maurizio Pansini $\cdot$ Marco Taviani
}

Received: 23 February 2011 / Accepted: 19 November 2011/Published online: 7 December 2011

(C) Springer Science+Business Media B.V. 2011

\begin{abstract}
The Mediterranean spongofauna is relatively well-known for habitats shallower than $100 \mathrm{~m}$, but, differently from oceanic basins, information upon diversity and functional role of sponge grounds inhabiting deep environments is much more fragmentary. Aims of this article are to characterize through ROV image analysis the population structure of the sponge assemblages found in two deep habitats of the Mediterranean Sea and to test their structuring role, mainly focusing on the demosponges Pachastrella monilifera Schmidt, 1868 and Poecillastra compressa (Bowerbank, 1866). In both study sites, the two target sponge species constitute a mixed assemblage. In the
\end{abstract}

Guest editors: M. Maldonado, X. Turon, M. A. Becerro \& M. J. Uriz / Ancient animals, new challenges: developments in sponge research

M. Bo $(\bowtie) \cdot$ M. Bertolino · G. Bavestrello

Dip. Scienze della Vita e dell'Ambiente, Università

Politecnica delle Marche, Via Brecce Bianche, 60131

Ancona, Italy

e-mail: m.bo@univpm.it

S. Canese - M. Giusti · M. Angiolillo

ISPRA, Via Casalotti 300, 00166 Rome, Italy

M. Pansini

Dip. per lo Studio del Territorio e delle sue Risorse, Università degli Studi di Genova, Corso Europa 26, 16132 Genoa, Italy

M. Taviani

ISMAR-CNR, Via Gobetti 101, 40129 Bologna, Italy
Amendolara Bank (Ionian Sea), where $P$. compressa is the most abundant species, sponges extend on a peculiar tabular bedrock between 120 and $180 \mathrm{~m}$ depth with an average total abundance of $7.3 \pm 1.1$ specimens $\mathrm{m}^{-2}$ (approximately $230 \mathrm{gWW} \mathrm{m}^{-2}$ of biomass). In contrast, the deeper assemblage of Bari Canyon (average total abundance $10.0 \pm 0.7$ specimens $\mathrm{m}^{-2}$, approximately $315 \mathrm{gWW} \mathrm{m}^{-2}$ of biomass), located in the southwestern Adriatic Sea between 380 and $500 \mathrm{~m}$ depth, is dominated by $P$. monilifera mixed with living colonies of the scleractinian Madrepora oculata Linnaeus, 1758, the latter showing a total biomass comparable to that of sponges $\left(386 \mathrm{gWW} \mathrm{m}^{-2}\right)$. Due to their erect growth habit, these sponges contribute to create complex three-dimensional habitats in otherwise homogenous environments exposed to high sedimentation rates and attract numerous species of mobile invertebrates (mainly echinoderms) and fish. Sponges themselves may represent a secondary substrate for a specialized associated fauna, such zoanthids. As demonstrated in oceanic environments sponge beds support also in the Mediterranean Sea locally rich biodiversity levels. Sponges emerge also as important elements of benthic-pelagic coupling in these deep habitats. In fact, while exploiting the suspended organic matter, about $20 \%$ of the Bari sponge assemblage is also severely affected by cidarid sea urchin grazing, responsible to cause visible damages to the sponge tissues (an average of $12.1 \pm 1.8 \mathrm{gWW}$ of individual biomass removed by grazing). Hence, in deep-sea ecosystems, not only the coral habitats, but also the grounds of massive sponges 
represent important biodiversity reservoirs and contribute to the trophic recycling of organic matter.

Keywords Deep benthos - Porifera - Mediterranean Sea $\cdot$ Biodiversity $\cdot$ Pelagic-benthic coupling

\section{Introduction}

The Porifera fauna of the Mediterranean Sea is one of the best documented in the world although this holds particularly true only for habitats shallower than $100 \mathrm{~m}$. In fact, information on sponges inhabiting deeper settings is scant, fragmentary and sparse in the literature (Babic, 1922; Topsent, 1928; Vacelet, 1960, 1961, 1969, 1996; Uriz, 1981, 1983, 1984; Uriz \& Bibiloni, 1984; Zibrowius, 1985; Pansini, 1987; Uriz \& Rosell, 1990; Pansini \& Musso, 1991; Maldonado, 1992; Voultsiadou-Koukouras \& Van Soest, 1993, Boury-Esnault et al., 1994; Ilan et al., 1994, 2003; Magnino et al., 1999; Uriz \& Maldonado, 2000; Longo et al., 2002). Furthermore, most of these observations are derived from bottom sampling not deliberately targeting sponges in a systematic way. Sampling in the deep sea is often biased towards soft-bottom habitats, which are easier to sample by trawling than the lessaccessible hard substrata. The first in situ observations that focused on deep sea sponges are those carried out in the Cassidaigne Canyon, near Marseille, by Vacelet (1969) in a manned submarine (Soucoupe plongeante Cousteau: SP 300). In the last few years, the exploration of the deep sea realm, due to the implementation of non-invasive techniques such as Remotely Operated Vehicles (ROV), increased steadily. Using this technique, important new information were obtained on Mediterranean deep sea inhabitants, including sponges (Freiwald et al., 2009; Taviani \& Angeletti, 2009; Beuck et al., 2010; Mastrototaro et al., 2010; Vertino et al., 2010; Bo et al., 2011a).

The term sponge ground is commonly accepted as referring to the case of sponges dominating in size and abundance, and also often by the accumulation of skeletal remains, the seabed (Hogg et al., 2010). They commonly occur on patchy hard substrata surrounded by unstable soft bottoms, but some species are specialized to live on sand and mud. Deep-water sponge grounds are also known to occur in distinct areas where local environmental conditions are suitable for their, usually slow, growth (Hogg et al., 2010). Although in the Mediterranean Sea sponge beds have not been recorded so far, grey literature and fishermen bycatch indicate the existence of large sponge assemblages also for this temperate basin.

Seamounts and submarine canyons, intrinsically difficult to survey due to their rough topography and vigorous current regime, were chosen as study sites since they may host structured and diverse suspension feeders communities, in which Porifera often play a leading role (Bourcier \& Zibrowius, 1973; Boehlert \& Genin, 1987; Tunesi et al., 2001; Samadi et al., 2007; Freiwald et al., 2009; Clark et al., 2010; Hogg et al., 2010). In this context, the Amendolara Bank (Ionian Sea) (Fig. 1) has been extensively investigated in the past on its shallow euphotic top resulting in substantial information on the benthic coralligenous biota (Rossi \& Colantoni, 1976; Panetta et al., 1985; Perrone, 1985; Strusi et al., 1985; D'Addabbo Gallo et al., 1987; Cecere \& Perrone, 1988; Di Geronimo et al., 1998). On the contrary, no precise documentation was given for the deep mesophotic assemblages below $100 \mathrm{~m}$ depth, characterized by sparse rocks surrounded by muddy bottoms, suitable for the settling of deep suspension feeders such as sponges. The Bari Canyon (southwestern Adriatic Sea: Fig. 1), instead, is known to be an optimal area where to investigate the complex interplay between topographic setting, hydrologic regime and the biological response of benthic communities (Trincardi et al., 2007; Bianchelli et al., 2008). Indeed, recently, lush deep-water coral communities dominated by the frame-building scleractinians Madrepora oculata Linnaeus, 1758 and Lophelia pertusa Linnaeus, 1758, often intimately associated with sponges and serpulids, have been documented from the steep flanks and other hardbottom settings in the canyon system between 350 and $650 \mathrm{~m}$ depth (Freiwald et al., 2009). As the nearby deep water coral province of Santa Maria di Leuca (Taviani et al., 2005a, b; Longo et al., 2005; Freiwald et al., 2009; Mastrototaro et al., 2010; Rosso et al., 2010, with references therein), the Bari Canyon represents an important biodiversity hotspot dominated by suspension feeders, mainly corals and sponges. 
Fig. 1 Locations of the study areas (black dots) in the southern Italian seas: Amendolara Bank (Ionian Sea) and Bari Canyon (southern Adriatic Sea)

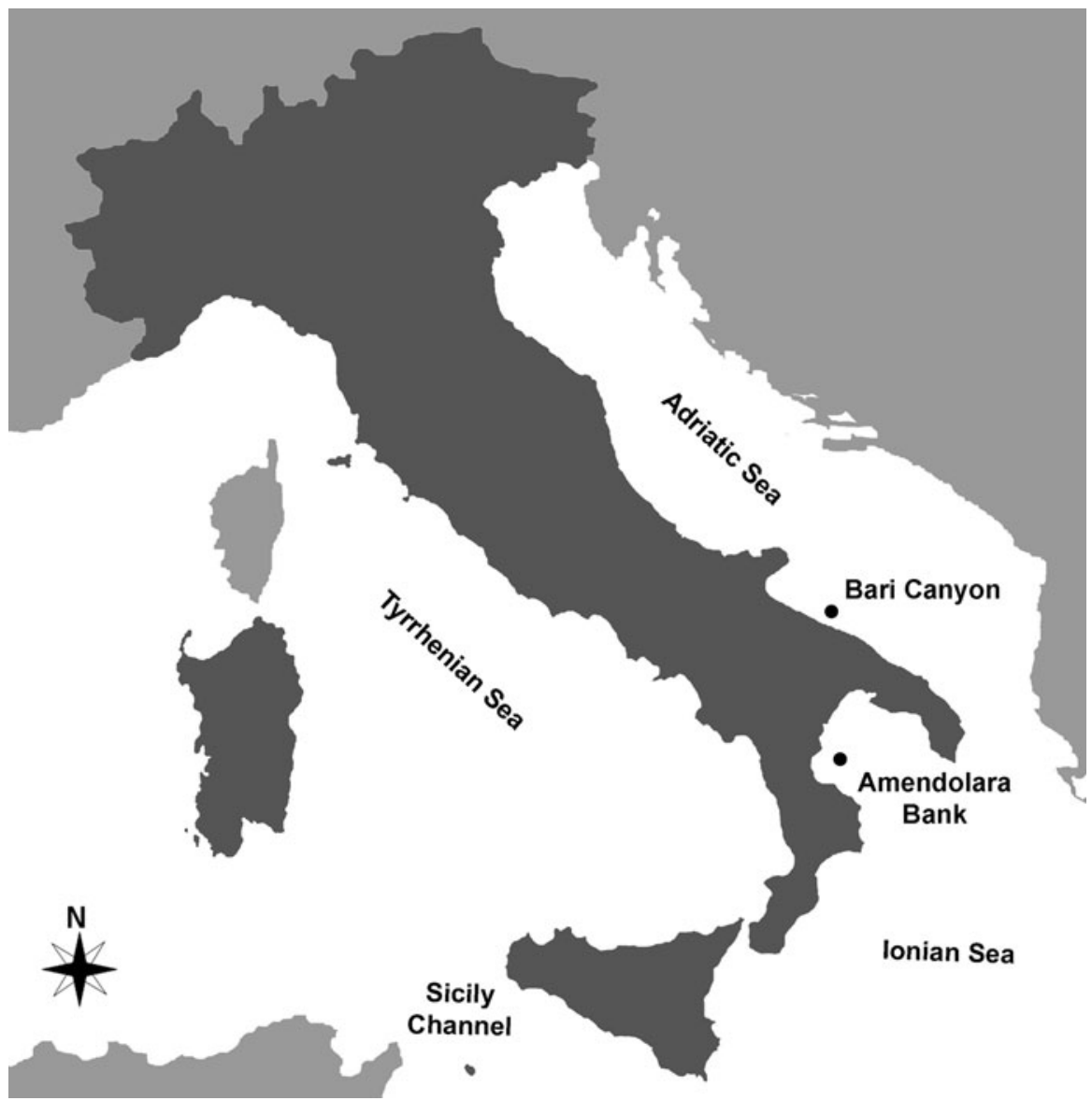

The aims of this study are to characterize the population structure and to test the structuring role of the sponge assemblages in deep habitats of the Mediterranean Sea mainly focusing on the two demosponges, Pachastrella monilifera Schmidt, 1868 and Poecillastra compressa (Bowerbank, 1866).

\section{Materials and methods}

Data collection and analyses

Data here presented were recorded during two ROV campaigns performed in August 2009 and July 2010 on board R/V Astrea of ISPRA (MoBioMarCal project) and R/V Urania of CNR (E.U. HERMIONE project) for the Amendolara Bank and the Bari Canyon, respectively. The ROV Pollux was equipped with a digital camera (Nikon D80, 10 megapixels), an underwater strobe (Nikon SB 400), and a high definition video camera (Sony HDR-HC7). In addition, it was equipped with a depth sensor, a compass, and two parallel laser beams providing a $10 \mathrm{~cm}$ scale for measuring the size of the sampled bottom areas.

Eleven adult sponges, 6 orange and 5 white, were collected from the Amendolara Bank with the ROV grabbers for taxonomic identification. Samples were fixed on-board in $4 \%$ formaldehyde in filtered sea water and then preserved in $70 \%$ ethanol. Spicule complement and skeletal architecture were examined under light microscopy following Hooper (2000). For SEM analyses, dissociated spicules were transferred onto stubs and sputter coated with gold then observed under a Philips XL20 SEM. No specimens were collected in the Bari Canyon and the species identification was based on the similarity with the Amendolara samples and on the base of a previous taxonomic work conducted in the sponge-white coral habitat of S. Maria Di Leuca (Longo et al., 2005). 
In total, 50 and 135 photographs have been analyzed with areas comprised between 0.5 and $3 \mathrm{~m}^{2}$, respectively, for the Amendolara Bank (54 m of total explored surface) and the Bari Canyon $\left(128 \mathrm{~m}^{2}\right.$ of total explored surface). Images were analyzed by ImageJ 1.33 software in order to record both abundance ( \pm SE, standard error) and size (height $\times$ width in $\mathrm{cm}$ ) of the sponges counted in the ROV images (211 measures in the Amendolara Bank and 770 in the Bari Canyon). Data were used to depict the community structure in terms of species identification, average abundance, bathymetric distribution, size-frequency distribution and percentage of sea urchin bites. Observations on the coral component (in the Bari Canyon) and on the associated organisms were also recorded for each analyzed image.

To depict the sponge biomass contribution in the two studied assemblages, the average wet weights (WW, expressed as $\mathrm{g} \mathrm{cm}^{-2} \pm \mathrm{SE}$ ) for the two studied species $\left(0.33 \pm 0.02\right.$ and $0.30 \pm 0.05 \mathrm{~g} \mathrm{~cm}^{-2}$, respectively, for Pachastrella monilifera and Poecillastra compressa) were calculated by weighting the collected specimens. With the same procedure, the biomass of the coral Madrepora oculata (0.73 \pm $0.01 \mathrm{~g} \mathrm{~cm}^{-2}$ ) was calculated for comparison. From the areas of the specimens, measured from ROV images with ImageJ software, the average individual biomass and the total biomass for each species and for each site were obtained. With the same method, the area and biomass grazed.

\section{Study sites}

Amendolara Bank is located on the western side of the Gulf of Taranto, in the northern Ionian Sea, about 10 miles offshore Corigliano Calabro (Fig. 1). It is a seamount with an almost ellipsoidal surface extending for $31 \mathrm{~km}^{2}$ from 200 to $26 \mathrm{~m}$ depth (Rossi \& Colantoni, 1976; Strusi et al., 1985; Di Geronimo et al., 1998; Romagnoli, 2004). Its top is quite rugged because of peaks, depressions and ridges (Rossi \& Colantoni, 1976; Cecere \& Perrone, 1988; Ceramicola et al., 2008). The bathymetric profile of the bank shows two shallow peaks, then, below $50 \mathrm{~m}$ depth, the bank is connected with a steep NW side to the flat continental platform, while the other flanks gently dip along the continental slope (Rossi \& Colantoni, 1976; Rossi \& Gabbianelli, 1978; Romagnoli, 2004). The flanks of the Amendolara Bank are characterized by frequent slides and by zones with gas emissions along the active tectonic structures (Ceramicola et al., 2008). The top of the mount is sediment-starved and characterized by the production and accumulation of skeletal hash and finer bioclastic sediment. Coralligenous bioconcretioning, mainly composed of algae, bryozoans, sponges and interspersed coarse sediments, occurs from the top to about $50 \mathrm{~m}$ depth (Cecere \& Perrone, 1988). Coarse sediments, becoming progressively finer with depth, are then replaced by mud below $80 \mathrm{~m}$ depth (Strusi et al., 1985). Annual oceanographic measurements document water transparency from about 10 to $16 \mathrm{~m}$, temperature from 13.3 to $18.4^{\circ} \mathrm{C}$ around $100 \mathrm{~m}$ depth (Cecere \& Perrone, 1988), and a predominant NS-flowing current (Grancini et al., 1969). More in detail, the site explored during the ROV survey is located on the bank SE flank at $39^{\circ} 50^{\prime} 17^{\prime \prime} \mathrm{N}-16^{\circ} 48^{\prime} 52^{\prime \prime} \mathrm{E}$ between $120-180 \mathrm{~m}$ Here, the area is characterized by a 'tabular' bedrock interrupted at places by rounded peaks draped by muddy sediment as for the adjacent sea bottom.

Bari Canyon is a remarkable, 30-km long and 10-km wide, WE-trending structure cutting the Apulian outer shelf (Fig. 1). It is characterized by multiple heads and two main branches (Trincardi et al., 2007). The northern branch is a narrow, straight incision with a slight steepness. The other branch is wider, asymmetric, U-shaped with a very steep southern wall and a more complex northern side (Turchetto et al., 2007). The Bari Canyon represents a sort of channel through which suspended fine sediment generated by the Po River (the primary fluvial system entering the Adriatic Sea) is conveyed into the deep southern Adriatic basin through cascading water masses (Ridente et al., 2007; Trincardi et al., 2007; Turchetto et al., 2007). It also conveys nutrients representing an important source of food nourishing the deep communities (Bianchelli et al., 2008). The explored area during our ROV survey is located at $41^{\circ} 17^{\prime} 15^{\prime \prime} \mathrm{N}-17^{\circ} 16^{\prime} 38^{\prime \prime} \mathrm{E}$, between 380 and $500 \mathrm{~m}$ depth, along the canyon's southern branch.

\section{Results}

The studied species (Fig. 2)

Pachastrella monilifera and Poecillastra compressa are two demosponge species belonging to the Order 

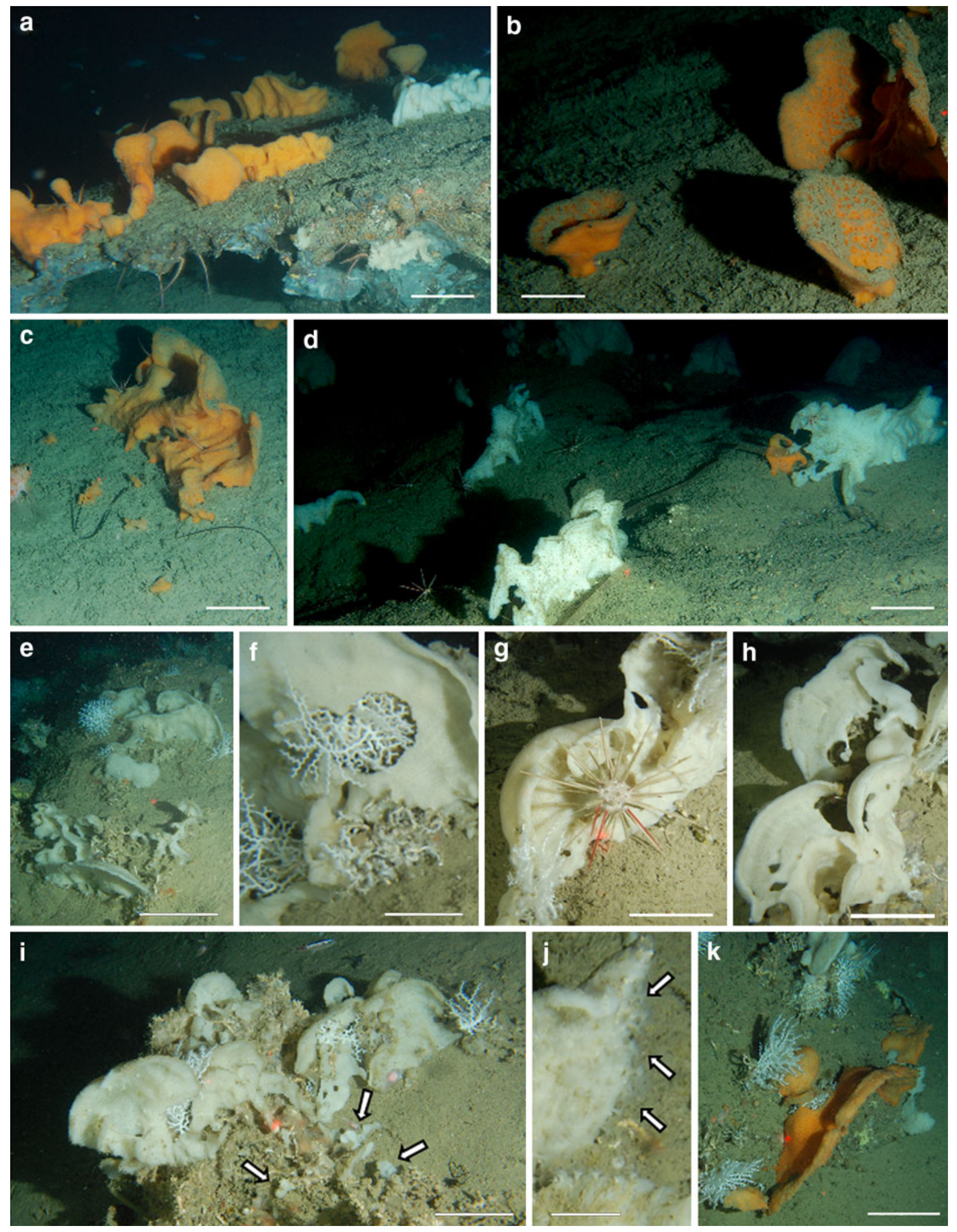
4 Fig. 2 ROV exploration of the sponge assemblages. a-d Amendolara Bank (120-180 m depth). a Poecillastra compressa and Pachastrella monilifera colonizing the upper side of a tabular bedrock. Below the rock, in the sheltered side, are visible numerous encrusting sponges and ophiuroids. b Cup-like and fan-like shaped specimens of $P$. compressa entrapping in a network the thin sediment over their surface. c Plate-like adult specimen of $P$. compressa surrounded by numerous juveniles visible on the muddy bottom. d Plate-like specimens of $P$. monilifera found on the detrital bottom. Cidarid sea urchins are visible between the specimens. e-k Bari Canyon (380-500 m depth). e Assemblage of fan-like specimens of $P$. monilifer $a$ and Madrepora oculata. f Close sponge-white coral association. g Cidarid sea urchin grazing sponge tissues. $\mathbf{h}$ Traces of the grazing activity of sea urchins on the tissues of $P$. monilifera. i Adult specimens of $P$. monilifera surrounded by juveniles (white arrows) growing on dead coral skeletons. $\mathbf{j}$ Zoanthid polyps (white arrows) growing on a specimen of $P$. monilifera. $\mathbf{k}$ Specimens of $P$. compressa in the assemblage. Scale bar e $20 \mathrm{~cm} ; \mathbf{a}-\mathbf{d}, \mathbf{h}-\mathbf{i}, \mathbf{k} 10 \mathrm{~cm} ; \mathbf{f}-\mathbf{g}, \mathbf{j} 3 \mathrm{~cm}$

Astrophorida sharing a great morphological and dimensional plasticity, which allow them to grow in a wide variety of different environments and on several types of substrate. Usually, P. monilifera is described as massive or cup-like in shape, and generally white in colour, while $P$. compressa is reported as plate- or cup-like, and orange in colour when observed alive (Uriz, 1978, 1982; present study). The latter has been reported also white or grey, but exsiccation and fixation may cause colour loss, as observed in our samples.

The spicular complements were compared with literature data (Maldonado, 2002) to verify the taxonomic identification of the samples. On the base of the spicular complement, all white specimens collected on the Amendolara Bank are attributed to P. monilifera (Fig. 2a, d), while all orange specimens are described as $P$. compressa (Fig. 2a-c). Colour, therefore, represented a good identification character for both species in the analysis of the studied ROV images.

Average sizes of the sponges are very similar both between the two species and between the two sites. They range between $6.9-7.2 \pm 0.2-0.6 \times 10.3-$ $11.7 \pm 0.3-1.0 \mathrm{~cm}$ for $P$. monilifera and between 8.1-8.2 $\pm 1.2-0.4 \times 11.9-12.6 \pm 0.7-2.3 \mathrm{~cm}$ for $P$. compressa, for Amendolara Bank and Bari Canyon, respectively. Specimens of both species grow more slowly in height than in width. The equations describing the ratio between width and height of the specimens of increasing size are very similar in both species $(y=1.28 x+1.24$ and $y=1.38 x+0.77$ for $P$. compressa from the Amendolara Bank and $P$. monilifera from the Bari Canyon, respectively) (Fig. 3a, b). The size-frequency distributions of height and width of both species are unimodal with a mode in the classes 4-6 cm both for height and width and a long tail of rare large specimens (Fig. 3c-f).

In both sites, fan-shaped sponges may show the same orientation on large portions of the sea floor (Fig. 2a, d, e, i), and this habit, in the assemblage of Bari Canyon, is shared also by the coral colonies. In addition, due to silting, especially $P$. compressa shows a characteristic network of sediment deposited on its mucous ectosoma, around the oscula (Fig. 2b).

Large groups of close fan-like specimens (up to 10 individuals) of both species are commonly observed on the sea bottom. In both sites, younger specimens are found surrounding adults on the hard substrates or on the dead coral colonies (Fig. 2c, i). As soon as they grow in height, both species develop a fan-like shape (Fig. 2). However, P. compressa shows thicker and more regular laminae that are able to fold up forming cup-shaped specimens (Fig. 2a, b), while P. monilifera generally forms thinner laminae with a folded upper border (Fig. 2d, h).

Abundance, biomass and bathymetric distribution

Pachastrella monilifera and Poecillastra compressa are the major sponge components in the benthic assemblages settling the deepest reaches of the Amendolara Bank (Fig. 2a-d) and the Bari Canyon (Fig. 2e-k). In the Amendolara Bank, the most abundant species is $P$. compressa $(70 \%$ of the 270 observed sponges), while in the Bari Canyon P. monilifera is dominant $(97.2 \%$ of the 1,043 observed sponges). The total average sponge abundance is slightly lower in the Amendolara Bank respect to the Bari Canyon $(7.3 \pm 1.1$ and $10.0 \pm 0.7$ specimens $\mathrm{m}^{-2}$, respectively) (Fig. 3). The Amendolara assemblage shows a patchy distribution, with elevated rocky areas characterized by high sponge densities (up to about 27 specimens $\mathrm{m}^{-2}$ ) interspersed with silted hard substrates deprived of visible epifauna. The assemblage is mixed, with both species contributing to the total abundance $(2.6 \pm 0.7$ and $4.7 \pm 0.9$ specimens $\mathrm{m}^{-2}$ for $P$. monilifera and $P$. compressa, respectively) (Fig. 3). The assemblage of Bari Canyon shows very high maximal total densities (up to 50 
Fig. 3 Sponge morphometry. a, b Ratio between width and height of Poecillastra compressa and Pachastrella monilifera. c-f Size-frequency distributions of height and width of the two sponge species
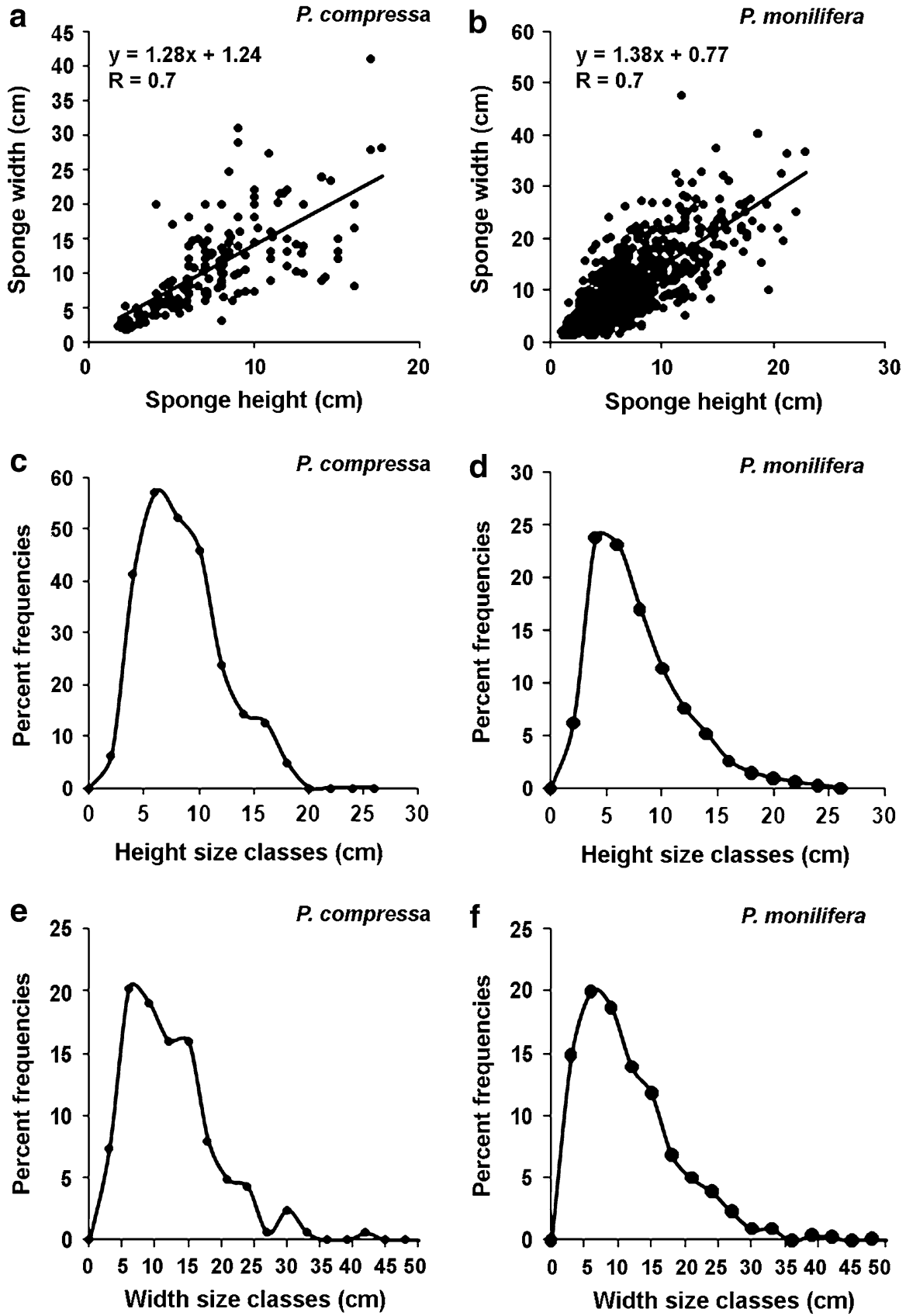

specimens $\mathrm{m}^{-2}$ ) and the sponges are widely distributed over the entire explored sea ground.

In the Bari assemblage, $P$. monilifera is dominant in the entire depth range considered $(9.7 \pm 0.7$ specimens $\mathrm{m}^{-2}$ ), while $P$. compressa occurs more occasionally $\left(0.2 \pm 0.07\right.$ specimens $\left.\mathrm{m}^{-2}\right)$ (Fig. 5). On the Amendolara Bank (Fig. 4) instead, the maximum average abundance of $P$. compress $a$ is recorded in the first considered depth range $(120-140 \mathrm{~m})(8.6 \pm 1.6$ specimens $\mathrm{m}^{-2}$ ), then it decreases towards $1.9 \pm$ 1.0 specimens $\mathrm{m}^{-2}$ in the deepest depth range (160-180 m). P. monilifera, instead, shows its maximum abundance $\left(4.4 \pm 1.5\right.$ specimens $\left.\mathrm{m}^{-2}\right)$ in the intermediate depth range $(140-160 \mathrm{~m})$. Below $180 \mathrm{~m}$ depth, both species become extremely rare.

The total sponges biomass contribution is 230.3 and $315.5 \mathrm{gWW} \mathrm{m}^{-2}$, respectively, in the Amendolara Bank and in the Bari Canyon. In the first site, 


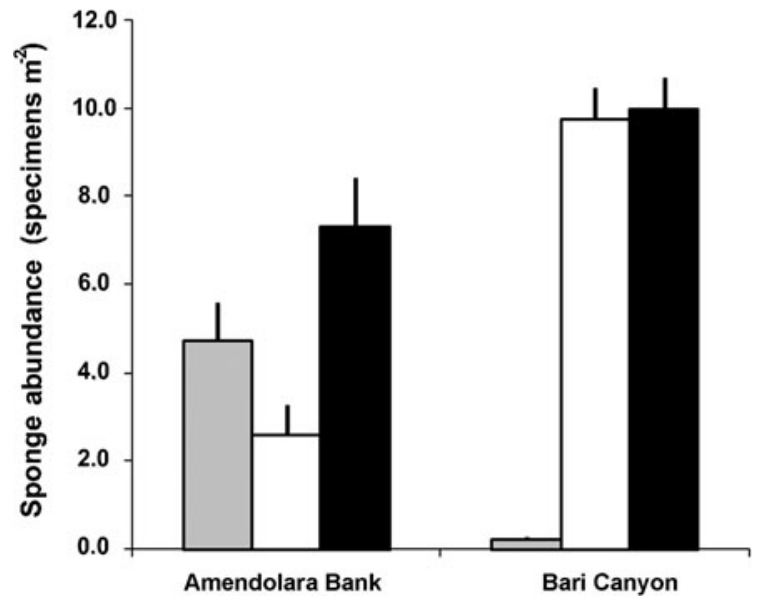

Fig. 4 Average sponge abundance distribution (specimens $\mathrm{m}^{-2} \pm \mathrm{SE}$ ) of the studied sponge assemblages, Amendolara Bank and Bari Canyon. Grey bars: Poecillastra compressa, white bars: Pachastrella monilifera, black bars: all sponges

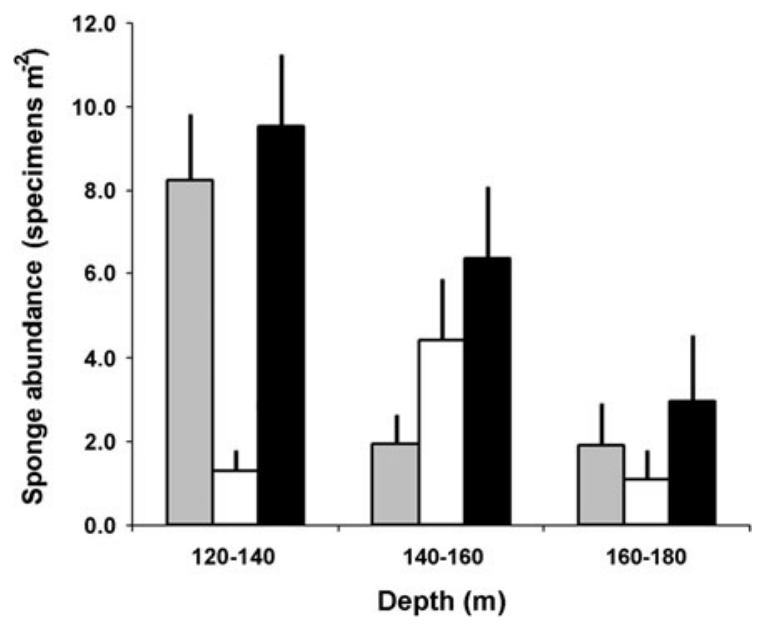

Fig. 5 Average sponge abundance at different depths (specimens $\mathrm{m}^{-2} \pm \mathrm{SE}$ ) of the Amendolara Bank sponge assemblage. Grey bars: Poecillastra compressa, white bars: Pachastrella monilifera, black bars: all sponges

P. monilifera occurs with a biomass of $90.7 \mathrm{gWW} \mathrm{m}^{-2}$ and $P$. compressa with $132.6 \mathrm{gWW} \mathrm{m}^{-2}$, while, in the second site, they occur with a biomass of 338.5 and $5.6 \mathrm{gWW} \mathrm{m}^{-2}$, respectively.

Functional role of deep sponges

In both under study sites, the sponge grounds, comprehensive of other occasional massive and encrusting sponges species, represent centres of attraction of numerous other species. In the Amendolara Bank, sponges grow in patches, both on the rocks sparse on the muddy sea floor and on the tabular, heavily silted rocks, elevating about $1 \mathrm{~m}$ from the bottom. In particular, on the latter, the massive sponges occupy only the upper side of the rocks (Fig. 2a), together with other occasional species tentatively attributed to the genera Mycale and Haliclona and small colonies of the scleractinian Dendrophyllia cornigera (Lamarck, 1816). The sheltered, lower side of rocks, often featuring cavities and crevices, is occupied by the encrusting blue sponge Hamacantha (Vomerula) falcula (Bowerbank, 1874) and by other unidentified encrusting and massive sponges. Many other species are found living in this benthic assemblage, such as octopuses, polychaetes and echinoderms, for examples, cidarids, Peltaster placenta (Müller-Troschel, 1842) and numerous ophiuroids (Fig. 2a). Several fish species are observed in this habitat, such as Helicolenus dactylopterus (Delaroche, 1809), Anthias anthias (Linnaeus, 1758), Callanthias ruber (Rafinesque, 1810), Merluccius merluccius (Linnaeus, 1758), Phycis blennoides (Brünnich, 1768), Aulopus filamentosus (Bloch, 1792), Macroramphosus scolopax (Linnaeus, 1758) and Scorpaena sp.

In the Bari Canyon, the sponge assemblage settles on hard substrates and often is intimately associated with living Madrepora oculata colonies (occurring with an abundance of $4.1 \pm 0.3$ colonies $\mathrm{m}^{-2}$, that corresponds to a biomass of $386 \mathrm{gWW} \mathrm{m}^{-2}$ ) (Fig. 2e-k). At places, branches of $M$. oculata emerge from the holes and crevices of the sponge tissues (Fig. 2f). Here, $P$. monilifera and $P$. compressa show a peculiar association with a small white zoanthid, which resembles Parazoanthus anguicomus (Norman, 1868), although no precise taxonomic identification was possible in absence of actual samples was gathered. Zoanthids, usually observed along the outer margin of their host, appear embedded in the sponge ectosome, emerging with the distal portion of the column (Fig. 2j). Other massive and encrusting sponges (such as Haliclona sp.) are more rarely observed. The megabenthic community is composed of the species commonly associated with white corals (such as the solitary scleractinian Desmophyllum dianthus (Esper, 1794) and the commensal polychaete Eunice norvegica (Linnaeus, 1767)), hydroids, ceriantharians, colonial scleractinians such as $D$. cornigera, polychaetes [such as Filograna sp. and Sabella pavonina 
(Savigny, 1818)], the echiurid Bonellia viridis (Rolando, 1821), crustaceans (such as Munida sp. and various shrimps), ascidians and echinoderms [such as cidarids, Echinus melo (Lamarck, 1816) and $P$. placenta]. Very few fish species are observed in the Bari Canyon assemblage: the rare Gaidropsarus granti (Regan, 1903) (Canese, pers. observ.), then P. blennoides, A. filamentosus, and Pagellus bogaraveo (Brünnich, 1768), the latter however, particularly abundant.

Sponges represent also a major source of organic carbon for some of the most abundant vagile organisms moving both on the soft bottom surrounding the rocks covered by the sponges and on the sponges themselves, namely cidarid sea urchins. At both sites, numerous specimens of $P$. monilifera and $P$. compressa show traces of predation ranging from ovoid erosions crossing the entire thickness of the sponge tissues to losses of large lobes of sponges. At the end of this process only some fragments of the sponge remain alive (Fig. 2d, f-i). Both species are affected by grazing, especially $P$. monilifera. In particular, in the Bari Canyon, where this species is dominant, the average percentage of sponges showing traces of grazing is $20.2 \pm 2 \%$. On average, the measured sponges may lose up to $70 \%$ of their surface because of grazing, while $12.1 \pm 1.8 \mathrm{gWW}$ is the average biomass loss caused by sea urchin predation (with a maximum of $56.3 \mathrm{gWW}$ for a single specimen).

\section{Discussion and conclusion}

Sponges may represent one of the most important components of deep megabenthic communities, both in the oceanic environments (Rice et al., 1990; Conway et al., 1991; Klitgaard, 1995; Rogers, 1999; Gerdes et al., 2008; Hogg et al., 2010) and in semi-enclosed basins, such as the Mediterranean Sea (Vacelet, 1969; PulitzerFinali, 1983; Magnino et al., 1999; Longo et al., 2005, Bo et al., 2011b). Differently from corals, the biodiversity and the ecological role of sponges in deep assemblages is far less appreciated, probably as a result of the difficulty to classify species only through ROV images or to collect small or encrusting specimens.

Among the most interesting sponge grounds described so far, vast Antarctic shelf sponge assemblages are noticeable. They occur between 50 and $350 \mathrm{~m}$ depth and are mainly constituted of hexactinellids reaching impressive values of biomass (Barthel \& Gutt, 1992; Gerdes et al., 2008). Other massive glass sponge reefs are found around 140-300 m depth along the northwestern continental margin of North America developing in areas of high sedimentation (Conway et al., 1991). Along the North Atlantic Ocean shelf edge, sponge grounds are mainly constituted by several demosponge species found at 600-1,000 depth (Hogg et al., 2010), while dense populations of the hexactinellid Pheronema carpenteri (Thomson, 1869) were discovered along the MidAtlantic Ridge, off Morocco and in the western Mediterranean basin between 500 and 1,600 m depth. This species is able to create grounds extending for kilometres and reaching in certain areas densities up to 6 specimens $\mathrm{m}^{-2}$ (Rice et al., 1990; Barthel, 1996). The existence of Mediterranean sponge assemblages, was recently reported from the white coral banks off Santa Maria di Leuca (Ionian sea) (Longo et al., 2005; Mastrototaro et al., 2010; Vertino et al., 2010) and also from the Bari Canyon, one of the areas here described (Freiwald et al., 2009). Finally, even if they do not constitute true sponge grounds, abundant assemblages of massive species were reported also on the rocks hosting wide mesophotic coral meadows along the Italian coast (Bo et al., 2011a). They represent the second most abundant component in these environments and generally live beneath the coral branching net, forming a sort of ground cover, exploiting the organic particulated matter sinking from above (Bo et al., 2011c).

This study represents the first description of dense paucispecific assemblages of Poecillastra compressa and Pachastrella monilifera, falling in the definition of sponge grounds in terms of abundance, extension, patchy distribution and ecological role (Hogg et al., 2010).

Despite the numerous literature records of these species, no ecological data exist on such dense assemblages, neither for the Mediterranean Sea nor for the Atlantic basin. Based also on unpublished records of these species in the Tyrrhenian Sea and on fishermen bycatch, the described assemblages may represent typical Mediterranean sponge grounds. The two studied sites differ in terms of composition of the benthic community, being the Amendolara Bank exclusively characterized by sponges (particularly $P$. compressa), while the Bari Canyon hosts a mixed assemblage of sponges (mainly $P$. monilifera) and Madrepora oculata. It is hypothesised that these assemblages are found in sites characterized by locally 
accelerated currents, enhancing seabed food particle supply (Duineveld et al., 2007; Carlier et al., 2009), therefore favouring suspension feeders, such as sponges. In both sites studied during this research, the presence of unidirectional bottom currents is hypothesised on the base of the uniform orientation of the fan-shaped sponges and corals (Wainwright \& Koehl, 1976; Warner, 1977; McDonald et al., 2003). Intensity of current is, however, moderate as supposed on the base of the heavy siltation evident on the specimens. In terms of biomass, the Bari assemblage shows the highest value. The oceanographic regime of the canyon together with the co-occurrence of corals, probably favour in this site higher levels of particulated organic matter, hence a more abundant community of suspension feeders. With respect to the Atlantic sponge ground described for the Porcupine Bank (an average of 1.5 specimens $\mathrm{m}^{-2}$ of $P$. carpenteri) (Rice et al., 1990), the Bari Canyon shows comparable values of biomass (315 and $372 \mathrm{gWW} \mathrm{m}^{-2}$, respectively, for the Mediterranean and Atlantic site), but obviously no reef structure.

The co-occurrence of the two species seems a common feature. Both species show an AtlanticMediterranean overlapped distribution. According to Maldonado (2002) and Cardenas (2010), in fact, records of these taxa from outside this region have to be attributed to close congeneric species.

$P$. monilifera was recorded along the entire Tyrrhenian and Ionian Italian coastlines, from Liguria to Apulia, and along the Sicilian coasts, with the exception of the Strait of Messina, but including the Sicilian Channel (Pansini \& Longo, 2003, 2008; Martinelli et al., 2007). Records are known also from the entire western Adriatic coastline, from Otranto to Istria. Concerning the rest of the Mediterranean Sea, the species was reported from the Gulf of Lions, from Catalunya and Balearic Islands, Alboran Sea and Algerian basin (Pansini \& Longo, 2003, 2008). In the Atlantic Ocean, the species shows an affinity for the temperate-cold fauna, being present in the coasts of Ireland, Azores, Canaries, coasts of Marocco and South Africa (Topsent, 1894, 1904, 1928; Ferrer Hernández, 1914; Stephens, 1915; Burton, 1926; Levi, 1960, 1967; Uriz, 1988; Boury-Esnault et al., 1994). Along the Italian peninsula $P$. compressa was reported for the Tyrrhenian Sea, including Sardinia and Corsica, the Ionian and Adriatic coast (Pansini \& Longo, 2003, 2008; Martinelli et al., 2007). In the rest of the
Mediterranean Sea, the sponge was reported in the same places as $P$. monilifera, while, concerning the Atlantic Ocean, it shows a higher affinity for the boreal fauna, having been recorded along the South African coast, Canaries, Azores, Portugal, Atlantic coasts of Spain and France, coast of Ireland, United Kingdom, Norway and Iceland (Topsent, 1894, 1904, 1913, 1928; Ferrer Hernández, 1914; Stephens, 1915; Burton, 1930, 1959; Levi, 1967; Borojevic et al., 1968; Boury-Esnault et al., 1994).

The studied sites show slight differences of sponge abundance: the assemblage of Bari Canyon is more homogeneous than that of Amendolara Bank (97 and 3\%, respectively, for $P$. monilifera and $P$. compressa for the Bari Canyon vs. 30 and $70 \%$ for the same species in the Amendolara Bank). Larval aggregation in a patchy rocky environment probably is among the most important factors influencing specimen distribution. In both sites, the settling of sponges is tightly connected with the presence of hard bottoms (both rocks or dead corals), therefore the species may show a variable distribution (as in the case of Amendolara Bank), with peaks of abundances alternated to areas characterized by heavy sedimentation that are not colonized.

Little information is available about the size structure of sponge populations (Turon et al., 1998). Sizefrequency distributions, obtained for the two species in the studied localities, indicate unimodal trends with peaks for the intermediate size classes and long tails. This kind of trend is very common in modular organisms like sponges and corals (Linares et al., 2008; Salvati et al., 2010). We hypothesise that the sponges grow quickly to increase the filtering efficiency and to avoid the sedimentation while their maximal size is probably constrained by the friction with the current (and partially by predation). Tails are composed of few specimens, probably living in peculiar sheltered habitat, that are able to continuously grow.

Regarding their bathymetric distribution, in the explored areas, $P$. compressa seems less bathophilic than $P$. monilifera being the most abundant species in the shallower investigated depth ranges of the Amendolara Bank and almost absent in the deepest areas of the Bari Canyon. In general, both $P$. compressa and $P$. monilifera are eurybathic species commonly recorded also inside the shallow water coralligenous concretions (Bertolino, 2011). While in deep habitats (more than $50 \mathrm{~m}$ depth), they show a 
characteristic massive fan-like or cup-like shape, in the coralligenous they are insinuating. This observation shows the importance of the coralligenous as centre of biodiversity (Ballesteros, 2006): this habitat, in fact, may host deep species characterized by a high phenotypic plasticity which allow them to live in the crevices of the concretions.

The numerous associated organisms found within the two under scrutiny communities indicate that $P$. monilifera and $P$. compressa, due to their massive, elevated morphology, may create three-dimensional habitats over homogeneous, sedimented hard bottoms, providing suitable refuges for other benthic organisms or for vagile fauna. Among the most specialized epibionts we found a small, white zoanthid tentatively attributed to the genus Parazoanthus, living as symbionts with both sponge species. Symbiotic relationships between sponges and zoanthids have been frequently observed in tropical and subtropical waters (Swain \& Wulff, 2007; Reimer et al., 2008), from shallow to deep habitats (Beaulieu, 2001). In the Mediterranean Sea, it is well documented the recurrent relationship between Parazoanthus axinellae Schmidt, 1862 and several species of sponges belonging to the genus Axinella (Sarà \& Vacelet, 1973; Previati et al., 2010), however, some species are more commonly found on hard bottom substrates (Salvati et al., 2010). As pointed out recently (MontenegroGonzález \& Acosta, 2010), the sponge morphology is an important trait in zoanthid habitat selection. In our case, the zoanthid probably finds refuge into the tissues of the sponge and, contemporaneously, exploits the water flow from an elevated position respect to the sedimented bottom, where it was never observed.

From an ecological point of view, these sponge species may play the same engineering role held by colonial, arborescent corals in deep environments (Klitgaard \& Tendal, 2004; Hogg et al., 2010; Bo et al., 2011c).

These sponges, moreover, represent an important step for the benthic-pelagic coupling in the studied assemblages. Even if many sponges avoid predation through the production of secondary metabolites (Clavico et al., 2006), the studied species are strongly exploited by the grazing activity of cidarid echinoids. The presence of sponge spicules in the gut content of these sea urchins was already observed in the Mediterranean Sea by Tortonese (1965) while several observations on the diet of these organisms, based on sponges and corals, were made in cold-water ecosystems (Jacob et al., 2003). Previous authors (Freiwald et al., 2009, Vertino et al., 2010) reported the grazing activity of sea urchins on the coral component of the Bari assemblage, suggesting that these grazers may represent the most important biotic constraint for these communities. The grazing activity has a considerable impact also on the sponge component. We have estimated, in fact, that about $1 / 5$ of the sponge specimens living in the studied sites shows traces of foraging. Since cidarids are known to be widely distributed on the Mediterranean soft bottoms, it is plausible that the organic faecal pellets produced by these vagile predators are then released both within the assemblage and in its neighbourhood, fertilizing the area in the proximity of these habitats.

Due to the high local biodiversity supported by these ecosystems, to the important functional roles held by the sponge components and to their vulnerability towards trawling activities, it is strongly recommended to pursue, also for these deep habitats, protective measures, as suggested for the recently discovered mesophotic coral meadows and Atlantic sponge grounds (Hogg et al., 2010; Bo et al., 2011a).

Acknowledgements We are grateful to Masters, Crew and shipboard staff onboard R/V Astrea and R/V Urania during MoBioMarCal (August 2009) and ARCADIA (March 2010) missions, respectively. We would like to thank Dr. Sinniger (Bangor University, UK) for his suggestions concerning zoanthid taxonomy. The work in the Amendolara Bank has been conducted by ISPRA (ex ICRAM), within the project no. 327, and financed by the Calabrian Regional Council for Environment. The work undertaken through MoBioMarCal is affiliated to the European Census of Marine Life. The ROV investigation of the Bari Canyon has been partly funded by the E.U. HERMIONE program (contract number 226354) and shiptime provided by CNR. This is ISMAR-CNR, Bologna scientific contribution no. 1742

\section{References}

Babic, K., 1922. Monactinellida und Tetractinellida des Adriatischen Meeres. Zoologische Jahrbücher, Abteilung für Systematik, Geographie und Biologie der Tiere 46: 217-302.

Ballesteros, E., 2006. Mediterranean coralligenous assemblages: a synthesis of present knowledge. Oceanography and Marine Biology 44: 123-195.

Barthel, D., 1996. Fish eggs and pentacrinoids in Weddell Sea hexactinellids: further examples for the structuring role of sponges in Antarctic benthic ecosystems. Polar Biology 17: 91-99. 
Barthel, D. \& J. Gutt, 1992. Sponge associations in the eastern Weddell Sea. Antarctic Science 4: 137-150.

Beaulieu, S. E., 2001. Life on glass houses: sponge stalk communities in the deep sea. Marine Biology 138: 803-817.

Bertolino, M., 2011. Sponges of the Coralligenous Community in the Mediterranean Sea. Università Politecnica delle Marche, PhD Thesis: 1-162.

Beuck, L., A. Freiwald \& M. Taviani, 2010. Spatiotemporal bioerosion patterns in deep-water scleractinians from off Santa Maria di Leuca (Apulia, Ionian Sea). Deep Sea Research II 57: 458-470.

Bianchelli, S., C. Gambi, A. Pusceddu \& R. Danovaro, 2008. Trophic conditions and meiofaunal assemblages in the Bari Canyon and the adjacent open slope (Adriatic Sea). Chemistry and Ecology 24: 101-109.

Bo, M., G. Bavestrello, S. Canese, M. Giusti, M. Angiolillo, C. Cerrano, E. Salvati \& S. Greco, 2011a. Coral assemblages off the Calabrian Coast (South Italy) with new observations on living colonies of Antipathes dichotoma. Italian Journal of Zoology 78: 231-242.

Bo, M., M. Bertolino, M. Borghini, M. Castellano, A. Covazzi Harriague, C. G. Di Camillo, G. P. Gasparini, C. Misic, P. Povero, K. Schroeder \& G. Bavestrello, 2011b. Characteristics of the mesophotic megabenthic assemblage of the Vercelli Seamount (North Tyrrhenian Sea). PLoS One 6: e16357.

Bo, M., S. Canese, M. Giusti, C. Spaggiari, M. Angiolillo, E. Salvati, S. Greco \& G. Bavestrello, 2011c. Mesophotic coral forests of the Italian seas. Proceedings of the World Conference on Marine Biodiversity, Scotland: 23.

Boehlert, G. W. \& A. Genin, 1987. A review of the effects of seamounts on biological processes. In Keating, B. H., P. Fryer, R. Batiza \& G. W. Boehlert (eds), Seamounts, Islands and Atolls. Geophysical Monograph Series, Vol. 43: 319-334.

Borojevic, R., L. Cabioc \& C. Levi, 1968. Inventaire de la Faune Marine de Roscoff: Spongiares. Edition de la Station Biologique de Roscoff: 2-41.

Bourcier, M. \& H. Zibrowius, 1973. Les "boues rouges" déversées dans le canyon de la Cassidaigne (région de Marseille). Observations en soucoupe plongeante SP 350 (juin 1971) et résultats de dragages. Téthys 4: 811-842.

Boury-Esnault, N., M. Pansini \& M. J. Uriz, 1994. Spongiaires bathyaux de la Mer d'Alboran et du Golfe Ibéro-Marocain. Mémoires du Museum National D’Histoire Naturelle 160: $1-174$.

Burton, M., 1926. Description of South African sponges collected in the South African Marine Survey. Part I. Myxospongia and Astrotetraxonida. Fisheries Bulletin. Fisheries and Marine Biological Survey Division, Union of South Africa Reports 4: 1-29.

Burton, M., 1930. Norwegian sponges from the Norman Collection. Proceedings of the Zoological Society of London 2: 487-546.

Burton, M., 1959. Spongia. The Zoology of Iceland 2: 1-71.

Cardenas, P., 2010. Phylogeny, Taxonomy and Evolution of the Astrophorida (Porifera, Demospongiae). University of Bergen, PhD Thesis: 1-80.

Carlier, A., E. Le Guilloux, K. Olu, J. Sarrazin, F. Mastrototaro, M. Taviani \& J. Clavier, 2009. Trophic relationships in a deep Mediterranean cold-water coral bank (Santa Maria di
Leuca, Ionian Sea). Marine Ecology Progress Series 397: 125-137.

Cecere, E. \& C. Perrone, 1988. First contribution to the knowledge of macrobenthic flora of the Amendolara SeaMount (Ionian Sea). Oebalia 14: 43-67.

Ceramicola, S., D. Civile, A. Caburlotto, A. Cova, D. Accettella, M. Caffau, D. Cotterle, P. Diviacco, N. Wardell \& R. Ramella, 2008. Analisi morfo-sedimentaria del margine calabro ionico settentrionale. Proceedings of the GNGTS 2008 Conference: 423-424.

Clark, M. R., A. A. Rowden, T. Schlacher, A. Williams, M. Consalvey, K. I. Stocks, A. D. Rogers, T. D. O'Hara, M. White, T. M. Shank \& J. M. Hall-Spencer, 2010. The ecology of seamounts: structure, function, and human impacts. Annual Reviews of Marine Science 2: 253-278.

Clavico, E. E. G., G. Muricy, B. A. P. da Gama, D. Batista, C. R. R. Ventura \& R. C. Pereira, 2006. Ecological roles of national products from the marine sponge Geodia corticostylifera. Marine Biology 148: 479-488.

Conway, K. W., J. V. Barrie, W. C. Austin \& J. L. Luternauer, 1991. Holocene sponge bioherms on the western Canadian continental shelf. Continental Shelf Research 11: 771-790.

D’Addabbo Gallo, M., L. De Morone \& S. Grimaldi de Zio, 1987. Heterotardigrada of the Amendolara Shoal, High Ionian Sea. In Bertolani, R. (ed.), Biology of Tardigrades. Proceedings of the Fourth International Symposium on the Tardigrada, September 1985, Modena, Italy. Selected Symposia and Monographs: 93-101.

Di Geronimo, I., R. La Perna, A. Rosso \& R. Sanfilippo, 1998. Notes on two upper-circalittoral assemblages from the Amendolara Bank (Northern Ionian Sea). Bollettino Accademia Gioenia di Scienze Naturali 30: 243-262.

Duineveld, G. C. A., M. S. S. Lavaleye, M. J. N. Bergman, H. de Stigter \& F. Mienis, 2007. Trophic structure of a cold-water coral mound community (Rockall Bank, NE Atlantic) in relation to the near-bottom particle supply and current regime. Bulletin of Marine Science 81: 449-467.

Ferrer Hernández, F., 1914. Esponjas del Cantábrico. Parte $2^{\circ}$. III. Myxospongida. IV. Tetraxonida. V. Triaxonida. Trabajos del Museo Nacional de Ciencias Naturales, serie Zoológica 17: 3-44.

Freiwald, A., L. Beuck, A. Rüggeberg, M. Taviani \& D. Hebbeln, 2009. The white coral community in the Central Mediterranean Sea revealed by ROV surveys. Oceanography 22: 58-74.

Gerdes, D., E. Isla, R. Knust, K. Mintenbeck \& S. Rossi, 2008. Response of Antarctic benthic communities to disturbance: first results from the artificial benthic disturbance experiment on the eastern Weddell Sea Shelf, Antarctica. Polar Biology 31: 1469-1480.

Grancini, G., A. Lavenia \& F. Mosetti, 1969. Ricerche oceanografiche nel Golfo di Taranto (Indagini fisiche del luglio 1968). Atti dell'Istituto Veneto di Scienze, Lettere ed Arti 127: 309-326.

Hogg, M. M., O. S. Tendal, K. W. Conway, S. A. Pomponi, R. W. M. van Soest, J. Gutt, M. Krautter \& J. M. Roberts, 2010. Deep-Sea Sponge Grounds: Reservoirs of Biodiversity. UNEPWCMC Biodiversity Series no. 32. UNEPWCMC, Cambridge: 1-88.

Hooper, J. N. A., 2000. 'Sponguide'. Guide to Sponge Collection and Identification. http://www.qm.qld.gov. 
au/organisation/sections/SessileMarineInvertebrates/ spong.pdf.

Ilan, M., N. Ben-Eliahu \& B. S. Galil, 1994. Three deep water sponges from the Eastern Mediterranean and their associated fauna. Ophelia 39: 45-54.

Ilan, M., M. Gugel, B. S. Galil \& D. Janussen, 2003. Small bathyal sponge species from East Mediterranean revealed by a non-regular soft bottom sampling technique. Ophelia 57: $145-160$.

Jacob, U., S. Terpstra \& T. Brey, 2003. High-Antarctic regular sea urchins - the role of depth and feeding in niche separation. Polar Biology 26: 99-104.

Klitgaard, A. B., 1995. The fauna associated with outer shelf and upper slope sponges (Porifera, Demospongiae) at the Faroe Islands, northeastern Atlantic. Sarsia 80: 1-22.

Klitgaard, A. B. \& O. S. Tendal, 2004. Distribution and species composition of mass occurrences of large-sized sponges in the northeast Atlantic. Progress in Oceanography 61: 57-98.

Levi, C., 1960. Spongiaires des côtes occidentals africaines. Bullettin de l'Institut Francais d'Afrique Noire 22: 743-769.

Levi, C., 1967. Spongiaires d'Afrique du Sud. (3) Tetractinellides. Transactions of the Royal Society of South Africa 37: 227-256.

Linares, C., R. Coma, J. Garrabou, D. Díaz \& M. Zabala, 2008. Size distribution, density and disturbance in two Mediterranean gorgonians: Paramuricea clavata and Eunicella singularis. Journal of Applied Ecology 45: 688-699.

Longo, C., F. Mastrototaro \& G. Corriero, 2002. Sponge fauna associated with white corals from the Western Ionian Sea. Bollettino dei Musei e degli Istituti Biologici dell' Università di Genova 66-67: 118.

Longo, C., F. Mastrototaro \& G. Corriero, 2005. Sponge fauna associated with a Mediterranean deep-sea coral bank. Journal of the Marine Biological Association of the United Kingdom 85: 1341-1352.

Magnino, G., M. F. Gravina, P. Righini, F. Serena \& M. Pansini, 1999. Due Demosponge Lithistidi nuove per i mari italiani. Biologia Marina Mediterranea 6: 391-393.

Maldonado, M., 1992. Demosponges of the red coral bottoms from the Alboran Sea. Journal of Natural History 26: 1131-1161.

Maldonado, M., 2002. Family Pachastrellidae Carter, 1875. In Hooper, J. N. A. \& R. W. M. van Soest (eds), Systema Porifera: A Guide to the Classification of Sponges. Kluwer Academic, Plenum Publisher, New York, Boston, Dordrecht, London, Moscow: 141-164.

Martinelli, M., G. Bavestrello, B. Calcinai \& M. Taviani, 2007. Poriferi associati ai banchi di Coralli bianchi del Canale di Sicilia a Sud di Malta. Proceedings of the $68^{\circ}$ UZI Congress, Lecce.

Mastrototaro, F., G. D’Onghia, G. Corriero, A. Matarrese, P. Maiorano, P. Panetta, M. Ghepardi, C. Longo, A. Rosso, F. Sciuto, R. Sanfilippo, C. Gravili, F. Boero, M. Taviani \& A. Tursi, 2010. Biodiversity of the white coral and sponge community off Cape Santa Maria di Leuca (Mediterranean Sea). Deep Sea Research II 57: 412-430.

McDonald, J. I., A. K. McGuinness \& J. N. A. Hooper, 2003. Influence of re-orientation on alignment to flow and tissue production in a Spongia sp. (Porifera: Demospongiae:
Dictyoceratida). Journal of Experimental Marine Biology and Ecology 296: 13-22.

Montenegro-González, J. \& A. Acosta, 2010. Habitat preference of Zoantharia genera depends on host sponge morphology. Universitas Scientiarum 15: 110-121.

Panetta, P., B. Dell'Angelo \& F. Fiordiponti, 1985. I Poliplacofori del Banco dell' Amendolara (Golfo di Taranto). Oebalia 11: 767-769.

Pansini, M., 1987. Report on a collection of Demospongiae from soft bottoms of the eastern Adriatic Sea. In Clifford Jones, W. (ed.), European Contributions to the Taxonomy of Sponges. Sherkin Island Marine Station: 41-53.

Pansini, M., \& C. Longo, 2003. A review of the Mediterranean Sea sponge biogeography with, in appendix, a list of the demosponges hitherto recorded from this sea. Biogeographia, XXIV, Marine Biogeography of the Mediterranean Sea: Patterns and Dynamics of Biodiversity: 59-90.

Pansini, M. \& C. Longo, 2008. Porifera. In La checklist della flora e della fauna dei mari italiani (a cura di G. Relini). Ministero dell' Ambiente e tutela del territorio, Roma. Biologia Marina Mediterranea 15: 42-66.

Pansini, M. \& B. Musso, 1991. Sponges from trawl-exploitable bottoms of Ligurian and Tyrrhenian Seas: distribution and ecology. Marine Ecology 12: 317-329.

Perrone, A., 1985. Report on the biological survey of Amendolara Seamount: Nudibranchia of Amendolara Seamount. Journal of Molluscan Studies 51: 102.

Previati, M., M. Palma, G. Bavestrello, C. Falugi \& C. Cerrano, 2010. Reproductive biology of Parazoanthus axinellae (Schmidt, 1862) and Savalia savaglia (Bertoloni, 1819) (Cnidaria, Zoantharia) from the NW Mediterranean coast. Marine Ecology 31: 555-565.

Pulitzer-Finali, G., 1983. A collection of Mediterranean Demospongiae (Porifera) with, in appendix, a list of the Demospongiae hitherto recorded from the Mediterranean Sea. Annali del Museo civico di storia naturale Giacomo Doria 84: 445-621.

Reimer, J. D., F. Sinniger \& C. P. Hickman Jr., 2008. Zoanthid diversity (Anthozoa: Hexacorallia) in the Galapagos Island: a molecular examination. Coral Reefs 27: 641-654.

Rice, A. J., M. H. Thurston \& A. L. New, 1990. Dense aggregations of a hexactinellid sponge, Pheronema carpenteri in the Porcupine Seabight (Northeast Atlantic Ocean) and possible causes. Progress in Oceanography 24: 179-196.

Ridente, D., F. Foglini, D. Minisini, F. Trincardi \& G. Verdicchio, 2007. Shelf-edge erosion, sediment failure and inception of Bari Canyon on the south-western Adriatic margin (Central Mediterranean). Marine Geology 246: 193-207.

Rogers, A. D., 1999. The biology of Lophelia pertusa (Linnaeus, 1758) and other deep-water reef-forming corals and impacts from human activities. International Review of Hydrobiology 84: 315-406.

Romagnoli, C., 2004. Segnalazione di terrazzi deposizionali sommersi nelle Isole Eolie Occidentali (Alicudi-Filicudi). Memorie Descrittive della Carta Geologica d'Italia 58: $155-158$.

Rossi, S. \& P. Colantoni, 1976. Appunti sul Banco Amendolara nel Golfo di Taranto. Giornale di Geologia 2: 277-284.

Rossi, S. \& G. Gabbianelli, 1978. Geomorfologia del Golfo di Taranto. Bollettino della Società Geologica Italiana 97: 423-437. 
Rosso, A., A. Vertino, I. Di Geronimo, R. Sanfilippo, F. Sciuto, R. Di Geronimo, D. Violanti, C. Corselli, M. Taviani, F. Mastrototaro \& A. Tursi, 2010. Hard- and soft-bottom thanatofacies from the Santa Maria di Leuca deep-water coral province, Mediterranean. Deep Sea Research II 57: 360-379.

Salvati, E., M. Angiolillo, M. Bo, G. Bavestrello, M. Giusti, A. Cardinali, S. Puce, C. Spaggiari, S. Greco \& S. Canese, 2010. The population of Errina aspera (Hydrozoa, Stylasteridae) of the Messina Strait (Mediterranean Sea). Journal of the Marine Biological Association of the United Kingdom 90: 1331-1336.

Samadi, S., T. Schlacher \& B. Richer de Forges, 2007. Seamount benthos. In Pitcher, T. J., et al. (eds), Seamounts: Ecology, Fisheries \& Conservation. Blackwell, Oxford: 119-140.

Sarà, L. \& J. Vacelet, 1973. Ecologie des Démosponges. In Grassé, P. P. (ed.), Traité de Zoologie. VIII, Spongiaires. Masson, Paris: 462-576.

Stephens, J., 1915. Sponges of the coasts of Ireland. I. The Triaxonidand and part of the Tetraxonida. Fisheries, Ireland Scientific Investigations 4: 1-43.

Strusi, A., A. Tursi, E. Cecere, C. Montanaro \& P. Panetta, 1985. The Amendolara Seamount (High Ionian Sea): general description. Oebalia 11: 379-388.

Swain, T. D. \& J. L. Wulff, 2007. Diversity and specificity of Caribbean sponge-zoanthid symbioses: a foundation for understanding the adaptive significance of symbioses and generating hypotheses about higher-order systematics. Biological Journal of the Linnaean Society 92: 695-711.

Taviani, M. \& L. Angeletti, 2009. Un giardino sepolto nel Mar Adriatico. Darwin 32: 74-81.

Taviani, M., A. Freiwald \& H. Zibrowius, 2005a. Deep coral growth in the Mediterranean Sea: an overview. In Freiwald, A. \& J. M. Roberts (eds), Cold-Water Corals and Ecosystems. Springer-Verlag, Berlin Heidelberg: 137-156.

Taviani, M., A. Remia, C. Corselli, A. Freiwald, E. Malinverno, F. Mastrototaro, A. Savini \& A. Tursi, 2005b. First geomarine survey of living cold-water Lophelia reefs in the Ionian Sea (Mediterranean basin). Facies 50: 409-417.

Topsent, E., 1894. Etude monographique des Spongiaires de France I. Tetractinellida. Archives de Zoologie expérimentale et générale 2: 259-400.

Topsent, E., 1904. Spongiaires des Açores. Resultats des Campagnes Scientifique du Prince de Monaco 25: 1-279.

Topsent, E., 1913. Spongiaires provenant des campagnes scientifiques de la «Princesse-Alice» dans les Mers du Nord (1898-1899, 1906-1907). Resultats des Campagnes Scientifique du Prince de Monaco 45: 3-67.

Topsent, E., 1928. Spongiaires de l'Atlantique et de la Méditerranée, provenant des croisières du Prince Albert I de Monaco. Resultats des Campagnes Scientifique du Prince de Monaco 74: 1-373.

Tortonese, E., 1965. Fauna d'Italia. Echinodermata. Edizioni Calderini, Bologna: 380.

Trincardi, F., F. Foglini, G. Verdicchio, A. Asioli, A. Correggiari, D. Minisini, A. Piva, A. Remia, D. Ridente \& M. Taviani, 2007. The impact of cascading currents on the Bari Canyon System, SW Adriatic margin (Central Mediterranean). Marine Geology 246: 208-230.
Tunesi, L., G. Diviacco \& G. Mo, 2001. Observations by submersible on the biocoenosis of the deep-sea corals off Portofino promontory (Northwestern Mediterranean Sea). In Willison, J. H. M., J. Hall, S. Gass, E. L. R. Kenchington, M. Butler \& P. Doherty (eds), Proceedings of the First International Symposium on Deep-Sea Corals. Ecology Action Centre and Nova Scotia Museum, Halifax: 76-87.

Turchetto, M., A. Boldrin, L. Langone, S. Miserocchi, T. Tesi \& F. Foglini, 2007. Particle transport in the Bari Canyon (southern Adriatic Sea). Marine Geology 246: 231-247.

Turon, X., I. Tarjuelo \& M. J. Uriz, 1998. Growth dynamics and mortality of the encrusting sponge Crambe crambe (Poecilosclerida) in contrasting habitats: correlation with population structure and investment in defence. Functional Ecology 12: 631-639.

Uriz, M. J., 1978. Contribución a la Fauna de Esponjas (Demospongia) de Cataluña. Universitad de Barcelona. $\mathrm{PhD}$ Thesis: 1-367.

Uriz, M. J., 1981. Estudio sistemático de las esponjas Astrophorida (Demospongia) de los fondos de pesca de Arrastre, entre Tossa y Calella (Cataluña). Boletin del Instituto Español de Oceanografia 6: 8-58.

Uriz, M. J., 1982. Estudio sistemático de las esponjas del order Axinellida (Demosponga) de la Costa Brava (Cataluña). Actas II Simposio ibérico de estudios del Bentos Marino 2: 57-80.

Uriz, M. J., 1983. Présence de l'espèce Esperiopsis fucorum (Demospongia, Poecilosclerida) en Méditerranée. Vie Milieu 33: 237-240.

Uriz, M. J., 1984. Descripción de nuevas esponjas del litoral de Namibia (sudoeste de África). Resultados Expediciones Científicas 12: 107-116.

Uriz, M. J., 1988. Deep-water sponges from the continental shelf and slope off Namibia (Southwest Africa): classes Hexactinellida and Demospongia. Monografías de Zoología Marina 3: 9-157.

Uriz, M. J. \& M. A. Bibiloni, 1984. Esponjas Homosclerofóridas (Demospongia) del Litoral Catalán. Miscellánea Zoológica 8: 7-12.

Uriz, M. J. \& M. Maldonado, 2000. The genus Acanthodendrilla in the Mediterranean Sea with description of a new species. Zoosystema 22: 401-410.

Uriz, M. J. \& D. Rosell, 1990. Sponges from bathyal depths (1000-1750 m) in the Western Mediterranean Sea. Journal of Natural History 24: 373-391.

Vacelet, J., 1960. Eponges de la Méditerranée Nord-Occidentale récoltées par le "Président-Théodore-Tissier" (1958). Recherches et Travaux de Institut des Pêches Maritimes 24: 257-272.

Vacelet, J., 1961. Spongiaires (Démosponges) de la région de Bonifacio (Corse). Recherches et Travaux de la Station marine d'Endoume 22: 351-354.

Vacelet, J., 1969. Éponges de la roche du large et de l'étage bathyal de Méditerranée. Mémoires du Muséum National d'Histoire Naturelle 59: 146-219.

Vacelet, J., 1996. Nouvelles signalisations d'éponges profondes en Méditerranée. Mésogée 55: 107-114.

Vertino, A., A. Savini, A. Rosso, I. Di Geronimo, F. Mastrototaro, R. Sanfilippo, G. Gay \& G. Etiope, 2010. Benthic habitat characterization and distribution from two representative sites of the deep-water SML Coral Mound 
Province (Mediterranean). Deep Sea Research II 57: 380-396.

Voultsiadou-Koukouras, E. \& R. W. M. van Soest, 1993. Suberitidae (Demospongiae, Hadromerida) from the North Aegean Sea. Beaufortia-Institute of Taxonomic Zoology (Zoological Museum) University of Amsterdam 43: 176-186.

Wainwright, S. A. \& M. A. R. Koehl, 1976. The nature of flow and the reaction of benthic cnidarian to it. In Mackie, G. O. (ed.), Coelenterate Ecology and Behavior. Plenum, New York: 5-21.
Warner, G. F., 1977. On the shape of passive suspension feeders. In Keegan, B. F., P. O'Ceidigh \& P. J. S. Boaden (eds), Biology of Benthic Organisms. Pergamon, Oxford/New York: 567-576.

Zibrowius, H., 1985. Spongiaires hexactinellides vivant en mer Ionienne par $2000 \mathrm{~m}$ de profondeur. Rapports Commission Internationale pour l'Exploration Scientifique de la Mer Méditerraneé 29: 335-338. 